\title{
BLISTER BLIGHT (Exobasidium vexans) IN TEA AND ITS RELATIONSHIP WITH ENVIRONMENTAL CONDITIONS ${ }^{\prime}$ )
}

\author{
G. A. DE WEILLE ${ }^{2}$ )
}

\section{Contents}

SUMMARY

page

ZUSAMMENFASSUNG

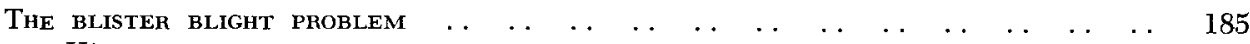

$\begin{array}{llllllllllllllllll}\text { History } & \ldots & \ldots & \ldots & \ldots & \ldots & \ldots & \ldots & \ldots & \ldots & \ldots & \ldots & \ldots & \ldots & \ldots & \ldots & \ldots & 185\end{array}$

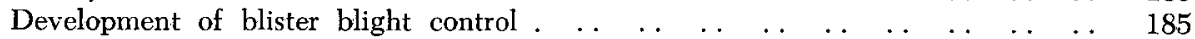

Crop losses caused by blister blight $\ldots \begin{array}{lllllllllll} & \ldots & \ldots & \ldots & \ldots & \ldots & \ldots & \ldots & \ldots & \ldots & 186\end{array}$

$\begin{array}{llllllllllllll}\text { THE FUNGUS CAUSING BLISTER BLIGHT } & \ldots & \ldots & \ldots & \ldots & \ldots & \ldots & \ldots & \ldots & \ldots & \ldots & \ldots & 187\end{array}$

$\begin{array}{lllllllllllllllll}\text { Description } & \ldots & \ldots & \ldots & \ldots & \ldots & \ldots & \ldots & \ldots & \ldots & \ldots & \ldots & \ldots & \ldots & \ldots & . & 187\end{array}$

$\begin{array}{llllllllllllllllll}\text { Sporulation } & \ldots & \ldots & \ldots & \ldots & \ldots & \ldots & \ldots & \ldots & \ldots & \ldots & \ldots & \ldots & \ldots & \ldots & \ldots & 187\end{array}$

$\begin{array}{llllllllllllllll}\text { Viability of the spores } & \ldots & \ldots & \ldots & \ldots & \ldots & \ldots & \ldots & \ldots & \ldots & \ldots & \ldots & \ldots & \ldots & 187\end{array}$

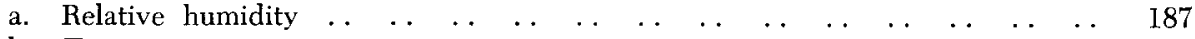

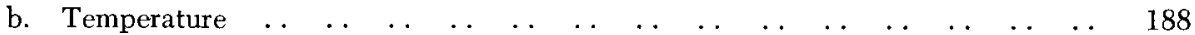

c. Light. $\begin{array}{lllllllllllllllll} & \ldots & \ldots & \ldots & \ldots & \ldots & \ldots & \ldots & \ldots & \ldots & \ldots & \ldots & \ldots & \ldots & \ldots & \ldots & 188\end{array}$

$\begin{array}{llllllllllllllllll}\text { Germination } & \ldots & \ldots & \ldots & \ldots & \ldots & \ldots & \ldots & \ldots & \ldots & \ldots & \ldots & \ldots & \ldots & \ldots & \ldots & 190\end{array}$

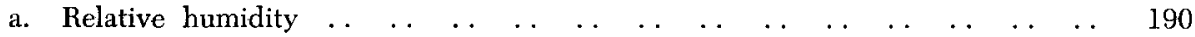

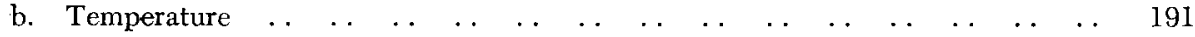

c. Light .

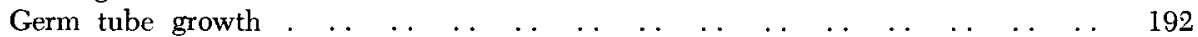

$\begin{array}{lllllllllllllllll}\text { Penetration } & \ldots & \ldots & \ldots & \ldots & \ldots & \ldots & \ldots & \ldots & \ldots & \ldots & \ldots & \ldots & \ldots & . & \ldots & 192\end{array}$

$\begin{array}{lllllllllllllllllll}\text { Blisters } & \ldots & \ldots & \ldots & \ldots & \ldots & \ldots & \ldots & \ldots & \ldots & \ldots & \ldots & \ldots & \ldots & \ldots & \ldots & \ldots & 192\end{array}$

Duration of development phases $\ldots \begin{array}{llllllllllll} & \ldots & \ldots & \ldots & \ldots & \ldots & \ldots & \ldots & \ldots & \ldots & \ldots & 193\end{array}$

a. Longevity of spores . . .

b. Germination and entry into the host .

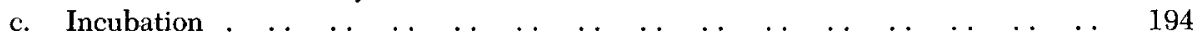

d. Last period until sporulation . $\ldots \begin{array}{lllllllllll} & \ldots & \ldots & \ldots & \ldots & \ldots & \ldots & \ldots & \ldots & \ldots & 194\end{array}$

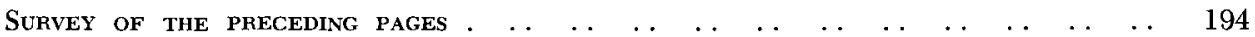

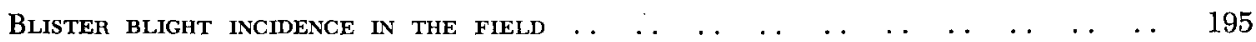

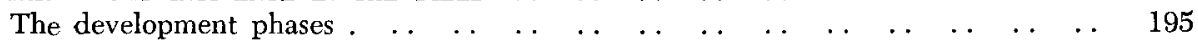

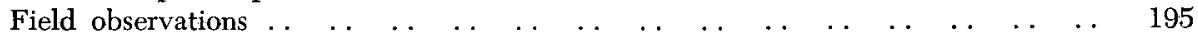

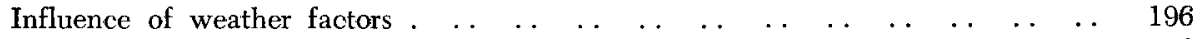

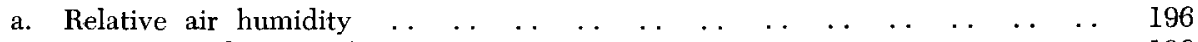

aa. Macroclimatic r.h. ..

ab. Microclimatic r.h. ..

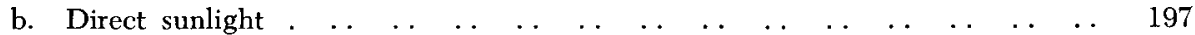

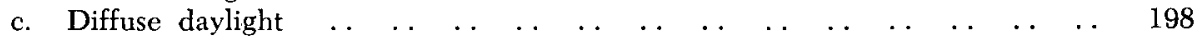

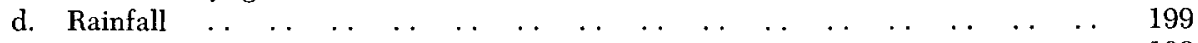

e. Mist .

f. Cloudiness . . .

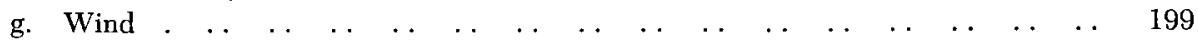

h. Thermals $\ldots \begin{array}{llllllllllllllll} & \ldots & \ldots & \ldots & \ldots & \ldots & \ldots & \ldots & \ldots & \ldots & \ldots & \ldots & \ldots & \ldots & \ldots & 200\end{array}$

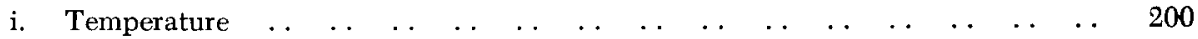

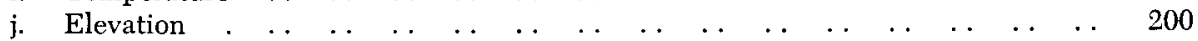

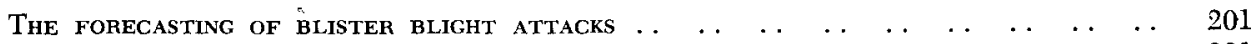

The s.v.r. system of chemical control . . .

1) Received for publication April 23, 1960.

2) Former: General Experiment Station of the A.V.R.O.S., Medan, Indonesia.

At present: Royal Neth. Meteorological Institute, de Bilt, Netherlands. 
$\begin{array}{lllllllllllllllll}\text { Short rounds } & . & \ldots & \ldots & \ldots & \ldots & \ldots & \ldots & \ldots & \ldots & \ldots & \ldots & \ldots & \ldots & \ldots & . & 202\end{array}$

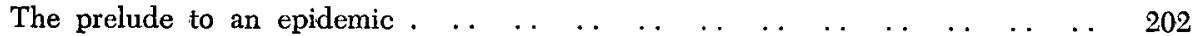

Calculation of sun valuation rates $\quad \ldots \begin{array}{lllllllllll} & \ldots & \ldots & \ldots & \ldots & \ldots & \ldots & \ldots & \ldots & \ldots & 203\end{array}$

$\begin{array}{llllllllllllllllll}\text { Application } & \ldots & \ldots & \ldots & \ldots & \ldots & \ldots & \ldots & \ldots & \ldots & \ldots & \ldots & \ldots & \ldots & \ldots & \ldots & 204\end{array}$

Comparative tests of warning systems .

The systems compared ..

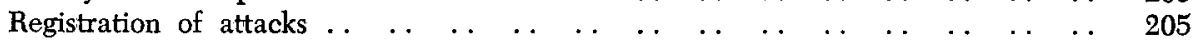

$\begin{array}{lllllllllllllllll}\text { The results } & \ldots & \ldots & \ldots & \ldots & \ldots & \ldots & \ldots & \ldots & \ldots & \ldots & \ldots & \ldots & \ldots & \ldots & \ldots & 206\end{array}$

$\begin{array}{lllllllllllllllllll}\text { RefERENCES } & \ldots & \ldots & \ldots & \ldots & \ldots & \ldots & \ldots & \ldots & \ldots & \ldots & \ldots & \ldots & \ldots & \ldots & \ldots & \ldots & 209\end{array}$

\section{SUMmary}

In this article a concise survey is given with respect to the significance of blister blight in tea cultivation in Indonesia, whereas the life cycle of the causative fungus, Exobasidium vexans Massee, is subjected to an analysis.

The basidiospores are extremely dependent on external factors, mainly (relative) air humidity (r.h.) and solar irradiation.

Regulating factors determine the duration of development phases outside the host (sporal stage, germination); these factors are r.h., temperature $(t)$ and visible light. Fungicidal factors are very low r.h., high $t$ and ultraviolet radiation. With respect to epidemics the factor radiation appears to be first in importance.

After having subjected the weather factors and their interrelation to a close scrutiny, the conclusion is that, in accordance with the results of laboratory research, sunlight is the principal factor governing blister blight attacks. In addition, subject to its topographical situation, the elevation, or altitude, of a plantation is decisive for its blister blight susceptibility.

Several scientists have tried to forecast blister blight attacks by means of alarm systems based on r.h. or sunshine in order that chemical treatment may be applied in time to minimize the expected epidemic. The author introduces his s.v.r.-system, by which fungicidal treatment is started or stopped in accordance with sun valuation rates, weighted sums of partly revalued sunshine duration data.

Statistical material proves the s.v.r.-system to be the most precise of the existing warning systems (33); it is also the easiest one.

By altering the danger limit indicated by the s.v.r.'s, the system should be adapted to local conditions.

\section{ZUSAMMENFASSUNG}

In diesem Artikel wird eine Ubersicht in gedrängter Form gegeben betreffs der Bedeutung der Teepocken in der Teekultur in Indonesien, während auch der Lebenskreislauf des Erregers dieser Krankheit, der Pilz Exobasidium vexans Massee, einer näheren Betrachtung unterzogen wird.

Die Basidiosporen sind sehr abhängig von den Umweltsbedingungen, hauptsächlich (relative) Luftfeuchtigkeit (R.F.) und Sonnenstrahlung.

Regelnde Faktoren bestimmen die Dauer der Entwickelungsphasen ausserhalb der Wirtspflanze (das Sporenstadium, die Keimung); diese Faktoren sind R.F., Temperatur (T) und sichtbares Licht.

Pilzabtötende Faktoren sind sehr niedrige R.F., hohe $\mathrm{T}$ und ultraviolette Strahlung. Hinsichtlich des epidemischen Auftretens der Teepocken hat sich der Strahlungsfaktor als der wichtigste herausgestellt.

Nachdem die Wetterfaktoren und ihr gegenseitiger Zusammenhang unter die Lupe genommen worden sind, kommt der Verfasser zur Schlussfolgerung dass, im Einklang mit den Resultaten seiner Labórversuche, mit Bezug auf das wohl oder nicht Auftreten der Teepockenangriffe Sonnenlicht der wichtigste Faktor ist. Darüber hinaus ist, in Zusammenhang mit der topographischen Lage, die Meereshöhe einer Pflanzung bestimmend für ihre Teepocken-Anfälligkeit.

Mehrere Forscher haben es versucht, die Teepockenangriffe vorherzusagen mittels Warnungssysteme, begründet auf R.F. oder Sonnenscheindauer (als Ersatzmittel für R.F.) damit die chemische Bekämpfung rechtzeitig vorgenommen werden könne und der zu erwartende Angriff geziigelt werde. 
Der Verfasser introduziert sein S.W.-System, gemäss welchem die Bekämpfung vorgenommen bzw. eingestellt wird nach Massgabe von Sonnenwerten, gewogene Gesamtsummen von teilweise neubewerteten Tagessummen der Sonnenscheindauer.

Statistisches Material liefert den Nachweis dass das S.W.-System das genaueste der untersuchten Systeme ist; es ist ausserdem das einfachste.

Durch die von den Sonnenwerten anzudeutende Gefahrgrenze zu verlegen kann das System lokalen Umständen angepasst werden.

\section{THE BLISTER BLIGHT PROBLEM}

\section{History}

Although blister blight has been known in Assam since the middle of the 19th century, it did not spread any further until the present century, during which it has become a serious menace to all tea growing in the Middle East and South East Asia. In 1898 the causative fungus received its scientific name Exobasidium vexans Massee.

In 1895 blister blight epidemics were reported in Upper Assam, in 1906 other regions of Assam became infected. The advance of the disease was not to be stopped. It appeared in Darjeeling (1908), Formosa (1912), Japan (1922) and Indo-China (1930). South India and Ceylon remained free from the disease until 1946, when a severe attack had to be reported in the latter country (TuBBs, 29).

In Indonesia the first blisters were detected on the East Coast of Sumatra in 1949. There the disease found an ideal medium: heavy rainfall evenly divided over the year (22) and, in addition, - due to wartime neglect and post-war labour shortage -, a very heavy canopy of shade trees covering all plantations. The rapidly spreading disease caused very severe damage wherever is appeared (REITSMA and VAN EMDEN, 24).

In 1951 blister blight spread to Java. The author himself witnessed the first outbreak in the Bengkulu district (S. Sumatra) in 1952 (SNIJDERS, 27).

\section{Development of blister blight control}

Indonesia has been able to profit by experience gained and research work done in other countries where blister blight had appeared earlier. The use of copper fungicides and the method of thinning out or stubbing up shade trees did not have to be discovered any more. When blister blight had invaded Northern Sumatra, VAN EMDEN (1) strongly advised Java tea planters to commence immediately with thinning out their shade trees before the disease broke out there. For the disease was bound to come to Java. And indeed, come it did, within a couple of months.

The first research workers engaged in blister blight were ReITSMa and VAN EMden $(3,4,23,24)$, two scientists from Java. On the East Coast of Java VAN HeLL and VeENSTra (8) set up fungicide trials, which proved the importance of copper fungicides. It was however Huxsmans (11), who developed blister blight control by his pioneering work during the years $1950-54$ at the blister blight laboratory at "Bah Butung" Estate, Siantar, that had meanwhile been set up by the A.V.R.O.S. (Algemene Vereniging van Rubberplanters ter Oostkust van Sumatra), Medan, - now called S.P.A. (Sumatra Planters Association) -, and two of its members, estate companies, the H.V.A. (Handelsvereniging "Amsterdam") and the N.H.M. (Nederl. Handelmaatschappij). At this laboratory Huxsmans (11) developed his warning system which, though it did 
not yet bring the problem to a final solution, must be considered as an important step in restricting the blister blight danger.

Though, of course, some mistakes were made in the early days of blister blight, we can say that the initiative of VAN HELL and the driving power of HuYsmans saved several estates from extremely high crop losses.

In the beginning Reitsma and Van Emden (23, 24) still believed in extinction of the causative fungus by collecting diseased leaves, pruning attacked bushes, burying infected loppings. Huysmans (11), just as TubBs (29) and GaDD (5), did not believe in eradication of Exobasidium, because millons of spores (1 single blister can produce 1.000 .000 spores) are constantly wafted across the tea plantations, regardless of leaf collecting and other efforts of the kind.

Now blister blight is kept under control, both by adapted methods of cultivation, - shade reduction combined with adequate systems of weeding, pruning and plucking (DE WEILLE, 37) -, and by protective chemical treatment (DE WEILLE, 36). These two kinds of control have become an accepted part of tea estate routine.

Progress could still be made by ameliorating the effect of fungicidal treatment by optimal use, i.e. fungicidal application restricted to periods normally preceding attacks. Huysmans (11), Homburg (9, 10) and VAN den KNaAP (13) have made studies of the possibility of making use of the distinct relationship between weather conditions and the virulence of blister blight attacks. Their work has led to warning systems. The author of this article also developed a system for the most effective use of fungicides under various conditions (De Weille, 33), which will be discussed further on.

\section{Crop losses by blister blight}

The economic significance of crop protection from blister blight is enormous. Over a 3’’2 years' period Loos (18) reported a yield loss of approx. 50 per cent in unprotected plots as compared with pre-blister blight yields and a loss of still 33 per cent as compared with plots protected by a copper fungicide (Ceylon). On estates, situated at a fairly high elevation, with adequate shade density and weeding system, but insufficient fungicidal protection, crop losses in 1950 amounted to at least 20-25 per cent (SCHWEIZER, 25) (Java). VAN EMdEN and VAN Hell (2) reported yield differences of approx. 25 per cent between sprayed and unprotected shade-free areas (N. Sumatra). Where the shade canopy was still present nearly complete crop losses were reported (VAN EMden, 1). De Jong (12) reported that the yield of sprayed and dusted plots was twice that of unprotected plots (N. India).

Table 1.

\begin{tabular}{c|c|c|c}
\hline \multirow{2}{*}{ Year } & \multicolumn{2}{|c}{ Production of factory-made tea in metric tons } \\
\cline { 2 - 3 } & estate-grown & $\begin{array}{c}\text { from small } \\
\text { holdings }\end{array}$ & total \\
\hline & & & \\
1950 & 23.178 & 12.206 & 35.348 \\
1951 & 34.005 & 12.508 & 46.513 \\
1952 & 30.572 & 6.705 & 37.277 \\
1953 & 31.323 & 5.716 & 37.039 \\
1954 & 38.564 & 8.336 & 46.900 \\
\hline
\end{tabular}


Most Indonesian tea is estate-grown. On Java a not inconsiderable part of the tea production is in the hands of small holders, who usually sell their green leaf to nearby estate factories. Owing to inadequate disease control measures this category has been most severely hit by blister blight (ScHweizer and RerTsma, 26). The following table (28) illustrates the influence of the disease on the ratio of estate and small holdings production.

\section{The Fungus CAUSING BLISTER BLIGHT}

\section{Description}

Exobasidium vexans Massee is an obligate parasite, the fruiting body of which is the characteristic white doughy or velvety blister. It consists of numerous compact bundles of hyphae situated close together and forming the hymenium. Having matured, these hyphae terminate in clavate basidia. When mature two nuclei from the basidium pass into spores after a fission. Gradually widening out near the apex, two (occasionally three, very rarely four) sterigmata are formed on the basidium. These projections each bear one spore at their apex. When they are ripe the initially unicellular basidiospores are divided in two almost equal parts by a septum. Then they are ready to be discharged.

Larger non-septate spores are only 6 to $14 \times 2.8$ to $4.3 \mu$ in size. Twocelled spores, still attached to the sterigmatum, measure 14-17 $\times 3.5-5.6 \mu$, whilst measurements of such spores, lying on the surface of the blister, had a range of $13-27 \times 2.3-6.5 \mu$ (GADD, 6 and Loos, 6, 16).

One single ripe blister can produce two million spores (Hursmans, 11), of which 10.000 can lie side by side on an area of $1 \mathrm{~mm}^{2}$ (Loos, 16). Lack of spores will consequently be the last factor inhibiting the development of epiphytotics.

The spores are enveloped in a thin sheath of mucilage, so adhesive that even heavy rainfall will not detach them from leaves or glass slides.

\section{Sporulation}

Spores are formed when the r.h. is sufficient. LAoH and Homburg (15) found spore formation and discharge possible in Java at a r.h. of 80 per cent. If it is less, Reitsma and VAN EMden (24) stated, the spores are not ejected from the blisters. According to Huxsmans (11), no spores are formed below 83 per cent r.h..

\section{Viability of the spores}

The germinative capacity of spores depends a.o. on conditions prior to germination, sometimes prevailing prior to ejection from the basidia. Factors of importance in this respect are r.h., $\mathrm{t}$ and sunshine or, in general : light.

\section{a. Relative humidity}

For the purpose of germination experiments HuYsmans used to collect blisters in the early morning hours. Such spores will show signs of germination ("pin points") after the shortest interval, sometimes even in complete darkness, which otherwise is unfavourable. In fact germination had been induced in these blisters by a favourable "previous history". Contrary to the practice of his predecessor the author kept his blisters in an atmosphere of 60-70 per 
cent r.h., in which no germination is induced, so that the factors influencing germination may be studied independently of previous circumstances.

In regard to the r.h. before germination trials were performed with ripe blisters (in the so-called stage 8; Hursmans, 11), which prior to the germination experiments were kept in atmospheres with 94, 89 and 75 per cent r.h.. The results were as follows.

Table 2.

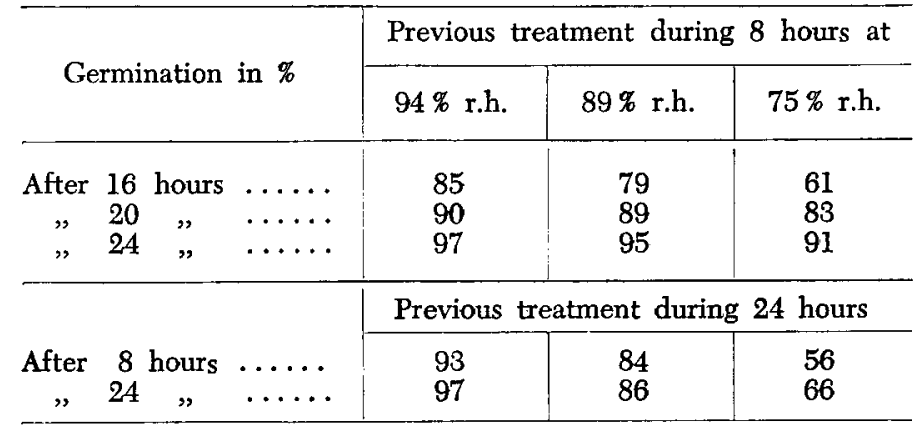

We can conclude that exposure to fairly low r.h. decreases the viability of blister blight spores in such a manner that later germination will proceed the slower in proportion as the said r.h. has been lower or the exposure to it longer. Fairly low r.h. can be called a regulating factor.

R.h. of 50 per cent or less is fungicidal.

\section{b. Temperature}

Exposure of spores to temperatures $>30^{\circ} \mathrm{C}$ will retard later germination. VAN DER KNAAP (13) states that temperatures of $35^{\circ} \mathrm{C}$ and higher are fungicidal.

\section{c. Light}

Spores whose germination is not conditioned by the blisters' previous history will not readily germinate in complete darkness. Subdued diffuse light is ideal. Therefore spores, collected in the early morning hours, will germinate later in complete darkness if the r.h. favours germination. Exposure to more intense diffuse daylight prior to germination results in a marked retardation of the germination process during the next 24 hours. Light of longer wave lengths is tolerated in higher intensities than is f.i. blue light which soon loses its inducive character to become a retarding factor. No fungicidal effect is brought about by visible light.

Half an hour of continuous direct sunlight proved to be long enough to kill both spores and germination tubes; the less dehydrated the spores, the sooner the sunlight effect becomes visible (Huysmans, 11). Sunny days can even cause blisters to turn brown before the sporing stage has been reached (VAN EMden and Rerrsma, 4). Sunlight effect prevails over that of a low r.h., as a humidity of 50 per cent or less is required to obtain the same result.

Some experiments performed by Huysmans, not published in extenso by that scientist, are described in the author's thesis (33). As the author was not yet completely convinced of the fungicidal action of sunlight, he performed new experiments in which additional effects such as a temperature rise, r.h. decrease or light absorption through glass, were avoided. These experiments were in favour of Hursmans, since they did prove "direct killing" (De WeILLE, 32, 33). 
Into a current-free cell or closet, $2 \mathrm{~m}$ high, spores, brushed off the blisters by means of a soft fine paint brush, were dropped through a little panel in the roof. The spore mass so obtained was exposed to radiation by electric lamps, burning behind a vertically slit diaphragm. The lamps could be moved up and down along a vertically mounted rail, so that they could follow the slowly falling blister blight spores on their way down to a table leaf where Petri dishes with object slides waited for them.

The distance between the little roof panel and the table leaf $\left(4 \frac{1}{\mathrm{ft}}\right)$ was covered in 1 hour's time (!).

The distance between lamps and spore mass was of the order of 70 to $80 \mathrm{~cm}$. By the time the spore mass came near the table, the lamps were moved so far down that the table leaf received no direct radiation, in order that no special microclimate could develop. In order to prevent heating of the bottom of the dishes by the artificial radiation, high-rimmed Petri-dishes of frosted glass were used.

Several types of lamps were used (see table 3) with different results.

In addition to every dish with irradiated spores, another dish was prepared with untreated spores originating from the same blisters (about a dozen) as those used for the irradiation experiment.

Irradiation was performed in an atmosphere of 25 to 29 degrees centigrade and a r.h. of 80 to 85 per cent. After treatment strips of wet, but not dripping wet, filter paper were laid beside the object glasses. Then the dishes were closed and taken to an air conditioned room with a constant $t$ of 21 centigrades where dew formation occurred.

Germination was investigated after 20 to 24 hours; at that time the dew was still present on the slides. The results were as follows :

Table 3.

\begin{tabular}{|c|c|c|c|c|c|c|c|c|}
\hline \multirow{3}{*}{ Trial } & \multirow{3}{*}{ Lamp type; $125 \mathrm{~V}$} & \multirow{3}{*}{$\begin{array}{l}\text { Duration } \\
\text { of irra- } \\
\text { diation }\end{array}$} & \multicolumn{4}{|c|}{ Number of spores } & \multicolumn{2}{|c|}{ Germination in $\%$} \\
\hline & & & \multicolumn{2}{|c|}{ treated } & \multicolumn{2}{|c|}{ untreated } & \multirow[b]{2}{*}{ treated } & \multirow[b]{2}{*}{$\begin{array}{c}\text { un- } \\
\text { treated }\end{array}$} \\
\hline & & & $\begin{array}{l}\text { germ- } \\
\text { inated }\end{array}$ & $\begin{array}{l}\text { not } \\
\text { germ- } \\
\text { inated }\end{array}$ & germ- & $\begin{array}{c}\text { not } \\
\text { germ- } \\
\text { inated }\end{array}$ & & \\
\hline $\begin{array}{l}1 \\
2 \\
3 \\
4\end{array}$ & $\begin{array}{l}\text { G.E. germicidal } \\
\text { lamp (ultra violet) } \\
15 \mathrm{~W}\end{array}$ & $\begin{array}{l}1 \text { hour } \\
1 \text { hour } \\
45 \text { min. } \\
30 \text { min. }\end{array}$ & $\begin{array}{r}20 \\
59 \\
59 \\
102\end{array}$ & $\begin{array}{l}401 \\
421 \\
320 \\
192\end{array}$ & $\begin{array}{l}276 \\
330 \\
250 \\
202\end{array}$ & $\begin{array}{l}72 \\
80 \\
49 \\
40\end{array}$ & $\begin{array}{r}4.8 \\
12.3 \\
16 \\
35\end{array}$ & $\begin{array}{c}79.3 \\
80.5 \\
83 \\
83\end{array}$ \\
\hline 5 & $\begin{array}{l}2 \text { Philips "Repro" } \\
\text { ultra high pressure } \\
\text { mercury lamps ; } \\
145 \text { W each }\end{array}$ & 1 hour & 39 & 231 & 301 & 35 & 14 & 89 \\
\hline 6 & $\begin{array}{l}\text { Philips TL discharge } \\
\text { tube ; } 40 \mathrm{~W}\end{array}$ & I hour & 110 & 61 & 247 & 131 & 64 & 65 \\
\hline 7 & $\begin{array}{l}2 \text { Philips "Photolita" } \\
\text { lamps; } 2 \times 250 \mathrm{~W}\end{array}$ & $30 \mathrm{~min}$. & 191 & 78 & 190 & 87 & 71 & 69 \\
\hline 8 & $\begin{array}{l}2 \text { Philips infrared } \\
\text { lamps; } 2 \times 250 \mathrm{~W}\end{array}$ & 1 hour & 40 & 18 & 95 & 23 & 69 & 81 \\
\hline
\end{tabular}


The above results are in accordance with the earlier mentioned opinion of Huysmans, whereas the relevant data are so marked that the following conclusions appear warranted :

1 Ultra-violet light is distinctly lethal to blister blight spores (only the trials $1-5$, in which appreciable amounts of ultra-violet radiation were emitted, show the effect of "direct killing").

2 Ultra-violet light of a wave length of appr. $2537 \AA$ (the greater part of the radiation emitted by the G.E. Germicidal discharge lamp) exercises a marked germicidal influence if the duration of the irradiation amounts to three quarters of an hour or more.

3 Actinic radiation of a wider wave length traject, such as emitted by Philips "Repro" lamps, resembling that of natural sunlight, is not second to radiation officially rated as "germicidal".

4 Irradiation during half an hour still produces a fungicidal effect; this effect is less vigorous than that of irradiation for longer durations.

5 Visible and infra-red light are not germicidal.

6 From these trials it has become more than plausible that sunlight is indeed able to kill spores direct by irradiation.

Owing to absorption our solar spectrum lacks rays of wave lengths below $2859 \AA$, so that results obtained with the G.E. germicidal lamp do not reflect the effect of solar u.v. light. In this respect the results obtained with the help of "Repro" lamps with a strong spectral line in the near u.v. (3655 $\AA$ ) are of greater significance.

At a distance from lamp to object of about $75 \mathrm{~cm}$ the radiation intensity of $3655 \AA$, when using 2 lamps, will amount to $0.002 \mathrm{~W} / \mathrm{cm}^{2}$; this is of the same order as the sun's ultra-violet radiation.

Of the TL-tubes the visible radiation is comparable to that of the "Repro" lamps. As "Repro" lamp are fungicidal and TL-tubes are not, the difference must, again, be imputed to u.v. radiation.

The TL-tubes' visible radiation is not comparable to that of the sun. Visible light of that strength was not used in the above experiments. It might be fungicidal. In earlier experiments however visible sunlight (sifted through ordinary glass) did not prove to be fungicidal when blister blight spores were exposed to it for up to an hour.

\section{Germination}

Germination of blister blight spores takes place only under special conditions. The viability of the spores is, of course, of great importance. Apart from the germinative capacity circumstances prior to germination, environmental conditions, exert a great influence on viable spores.

\section{a. Relative humidity}

A thin water film around the spore or a r.h. of 100 per cent (the water vapour condensing as dew around the spore) are conducive, if not necessary to germination. REITSMA (23), VAN EMden (23), GADD $(6,7)$ and Loos $(6.7,16)$ declared that spores can germinate in a drop of water. The latter two workers found that a thin film of water is more favourable than a hanging drop, where- 
as dew is ideal. Whilst germination is possible in a suspended drop, it was found at the General Experiment Station of the A.V.R.O.S. that spores generally failed to germinate in level drops.

There is, according to HuYsMans (11), no evidence of germination at r.h.'s of 97 per cent or less. LAOH and Homburg (15) observed slow germination at a 90 per cent r.h.; RerTsMa and VAN EMdeN (24) stated that germination even could occur on dry slides at r.h. of 80 per cent or more.

\section{b. Temperature}

HuYsmans (11) as well as VAN DER KNAAP (13) found germination at $25^{\circ} \mathrm{C}$ to proceed more rapidly than at $21^{\circ} \mathrm{C}$. The latter found higher $\mathrm{t}$ to be inhibitory; he stated that temperatures of $35^{\circ} \mathrm{C}$ and higher are even fungicidal.

\section{c. Light}

Not only before, but also during germination some light can quicken or retard the process.

Trials were performed with blister blight spores in an environment characterized by a maximal r.h. and monochromatic light. This medium was created in closed Petri dishes, covered with dark paper. Square "windows" had been cut out of the paper $(3 \times 3 \mathrm{~cm})$, on which Kodak colorimeter filters were placed. Under the diaphragm were blister blight spores on a slide covered with dew. Before the experiment the blisters had been kept in an environment of 60 to 70 per cent r.h., in which there is no tendency to germinate.

During a $\mathbf{4 0}$ hours' period the spores were kept in subdued diffuse light. The period was interrupted by two dark periods of 6 hours.

The effect of light was more marked than in the case of irradiation only prior to germination.

The results were as follows :

Table 4.

\begin{tabular}{|c|c|c|c|c|c|c|}
\hline \multicolumn{3}{|c|}{ Data re light } & \multicolumn{4}{|c|}{ Effect of light } \\
\hline $\begin{array}{c}\text { Kodak } \\
\text { filter } \\
\text { nr. }\end{array}$ & $\begin{array}{l}\text { Kind } \\
\text { of } \\
\text { light }\end{array}$ & $\begin{array}{l}\text { Wave length } \\
\text { of radiation } \\
\text { maximum }\end{array}$ & $\begin{array}{l}\text { Spores } \\
\text { germin- } \\
\text { ated }\end{array}$ & $\begin{array}{l}\text { Not } \\
\text { germ- } \\
\text { inated }\end{array}$ & $\begin{array}{l}\text { Per cent } \\
\text { germin } \\
\text { ation }\end{array}$ & $\begin{array}{l}\text { Length of } \\
\text { germination tubes }\end{array}$ \\
\hline$\overline{1}$ & $\begin{array}{l}\text { none } \\
\text { violet }\end{array}$ & $430-$ & $\begin{array}{r}0 \\
82\end{array}$ & $\begin{array}{l}281 \\
215\end{array}$ & $\begin{array}{r}0 \\
28\end{array}$ & \multirow{3}{*}{$\begin{array}{l}\text { only first signs of } \\
\text { germination } \\
\text { id. } \\
\text { id. } \\
\text { some outspoken } \\
\text { tubes formed }\end{array}$} \\
\hline $\begin{array}{l}2 \\
3\end{array}$ & $\begin{array}{l}\text { blue } \\
\text { blue- }\end{array}$ & $465 \mathrm{~m} \mu$ & 118 & 179 & 40 & \\
\hline 4 & $\begin{array}{l}\text { green } \\
\text { green }\end{array}$ & $\begin{array}{l}490 \mathrm{~m} \mu \\
520 \mathrm{~m} \mu\end{array}$ & $\begin{array}{l}121 \\
120\end{array}$ & $\begin{array}{l}132 \\
112\end{array}$ & $\begin{array}{l}48 \\
52\end{array}$ & \\
\hline $\begin{array}{l}6 \\
7\end{array}$ & $\begin{array}{l}\text { yellow- } \\
\text { green } \\
\text { yellow } \\
\text { orange }\end{array}$ & $\begin{array}{l}545 \mathrm{~m} \mu \\
580 \mathrm{~m} \mu \\
605 \mathrm{~m} \mu\end{array}$ & $\begin{array}{l}239 \\
183 \\
252\end{array}$ & $\begin{array}{l}60 \\
19 \\
29\end{array}$ & $\begin{array}{l}80 \\
91 \\
90\end{array}$ & \multirow{2}{*}{$\begin{array}{l}15 \times \text { spore length } \\
>15 \times \text { spore length } \\
\text { longer, already } \\
\text { branched } \\
\quad \text { id. } \\
\quad \text { id. }\end{array}$} \\
\hline $\begin{array}{c}8 \\
-\end{array}$ & $\begin{array}{l}\text { red } \\
\text { white }\end{array}$ & $\begin{array}{c}675 \mathrm{~m} \mu \\
-\end{array}$ & $\begin{array}{l}229 \\
258\end{array}$ & $\begin{array}{l}19 \\
32\end{array}$ & $\begin{array}{l}92 \\
89\end{array}$ & \\
\hline
\end{tabular}


The preliminary conclusions were that:

1 the experiment once more proved the necessity of subdued light for the germination;

2 the effect of irradiation prior to germination is increased by prolonging this irradiation period during germination;

3 radiation with wave lengths of $525 \mathrm{~m} \mu$ and more is most important. Light of shorter wave length is the less effective the shorter the wave length.

It could be calculated that the proportional intensities were of the same order except for filter nr. 8 (much higher intensity) (De WeILLE, 33).

\section{Germ tube growth}

It is obvious that the above influence of light can be split up into two phenomena, viz. 1) germinative induction and 2) germ tube growth, both subject to similar stimulation and retardation effects. This assumption was substantiated by small laboratory trials.

A temporary r.h. decrease to 70 per cent or less stops germ tube growth and so does bright daylight, not yet strong enough to be fungicidal. Visible light, more or less intense, of a sufficiently long duration, can either retard or stop germ tube growth. This influence is the stronger the longer the wave length is. Only u.v. radiation kills these fungal parts.

\section{Penetration}

Germination may commence within a few hours after the mature spore has found the ideal circumstances required. If its previous history does not entail any retardations the one or two (rarely three) germ tubes may be seen after 2-4 hours after the said ideal circumstances begin to prevail. After 3 hours under ideal conditions the germ tube length can amount to $1 / 10$ to $1 / 6$ the spore length. After 24 hours some of the tubes will be longer than the spore. When, in experiments, germinating spores were laid on young tea leaves, during the 3rd and 4th day spherical appressoria were formed in which the protoplasm concentrates. From the appressorium a mycelial strand, rich in protoplasm, enters the leaf tissue. On the other hand spores were often found to form fungal strands entering into the leaf tissue without an appressorium having first been formed.

It was found that no appressorium is formed if a hypha penetrates foliar tissue via the stomata in the lower surface of the leaf. A greater number of infective hyphae penetrate through the leaf cuticle on either side of the leaf after having formed an appressorium. Only young leaves, buds, petioles or shoots are invaded; the cuticle of old leaves cannot be pierced.

Penetration into a tea leaf can take place in complete darkness as well as in subdued diffuse light.

\section{Blisters}

In the epidermis the narrow infective hyphae widen out to normal size. Branching begins in the palisade tissue; in the spongy parenchyma mycelial growth is almost entirely intercellular. In the case of entry from beneath the hypha enters direct into the spongy parenchyma. Nutrients are extracted from 
the cells by lobed haustoria. Soon the invaded cells together form the translucent yellowish spot, known as the "blister" in its first stage.

HuYsmans (11) distinguished 10 stages in that part of the life cycle of blister blight which is visible to the naked eye.

Stage 1: a translucent light spot, visible only by its transparency, less than $y_{2}^{\prime} \mathrm{mm}$ in diameter;

stage 2: a light spot, still smaller than $1 \mathrm{~mm}$, but also visible from above;

stage 3: a light spot, shining like a drop of varnish, surrounded by a dark green circle; size 1 to $3 \mathrm{~mm}$;

stage 4: size 3 to $6 \mathrm{~mm}$ in diameter;

stage 5: upper leaf surface concave; cell enlargement has made the lower leaf surface bulge;

stage 6: tufts of now mature basidia expose themselves in the form of the white hymenium; spore formation is just commencing;

stage 7: clear white blisters, appr. 5 to $7 \mathrm{~mm}$ in diameter. In the 6th and 7 th stage spores are discharged; spore discharge may continue for 7 to 8 days ;

Apart from concave blisters there are also convex ones, sporulating on the upper leaf surface. These convex blisters form a small minority ;

stage 8: blisters have darkened slightly after sporing;

stage $9:$ a desiccated brown centre is visible;

stage 10: dead blister, dark brown to black. Dead blisters often break off, leaving holes in the leaf-blade.

Tea seems to have a natural resistance to blister blight, restricting fungus growth to a very limited round area of the leaf; mycelium of one blister does not move to another portion of the leaf and will not occupy more than its own spot, not exceeding $7 \mathrm{~mm}$ in diameter.

Apart from normal blisters there are other serious infections, not on leaf blades, viz. bud infections, always killing the infected bud, petiolar infections, usually causing the leaf to fall off and sometimes entailing infection of the axillary bud, and shoot infections which, if they encircle a sufficiently large part of the shoot, will kill its distal portion.

These kinds of infections inflict a damage more severe than that caused by ordinary leaf blisters. They are rare in well protected plots but prevail under heavy shade, along ditches and wood boundaries and, of course, in unprotected plots.

\section{Duration of development phases}

a. Longevity of spores

Germination sometimes commences 2 hours after the spore has alighted somewhere under ideal conditions. Meanwhile the rapidity of germination will vary considerably. Twelve or more hours may elapse before distinctly discernible germ tubes are formed. Awaiting better conditions, e.g. a higher r.h. for its germination, a spore can survive for about 4 to 5 days. 


\section{b. Germination and entry into the host}

Loos (16) recorded that the time required for germination, formation of the appressorium, and penetration into the leaf, is approximately 16 hours (probably under the most favourable laboratory conditions); TuBBs (29) stated that the entry of a germ tube into the leaf is accomplished in less than 24 hours. This period may last longer ; it may range from 1 to 4 days or longer. ReITSMA and VAN EMDEN (24) observed that spores already germinated on agar media could be kept alive for more than a week.

In the field many circumstances retard the life cycle of Exobasidium vexans. Once the spore has attached itself to a leaf, the time elapsing before entry into the tissue may last up to 9 days. In practice this period varies between wide limits, viz. 2 to 9 days.

\section{c. Incubation}

The period from entry to "translucent spot" (stage 1) varies in the field between 3 and 10 days.

\section{d. Last period until sporulation}

The time elapsing from stage 1 to the outbreak of basidia (stage 6) may last 6 to 9 days.

\section{SURVEY OF THE PRECEDING PAGES}

In regard to the life cycle of the organism causing blister blight the following matters were discussed:

1. regulating factors

for spore formation: r.h. $>80 \%$ is required;

" spore ejection : r.h. $>80 \%$ is required;

" germination : r.h. $>90 \%$ and subdued visible light are required;

r.h. $<100 \%$ and low r.h. previous to germination retard it; high $t$ until $29^{\circ} \mathrm{C}$ promotes germination;

" germ tubegrowth: subdued visible light promotes it ;

more visible light retards it ;

r.h. $<70 \%$ stops germ tube growth.

2. fungicidal factors : u.v. radiation,

r.h. $<50 \%$,

t. $>35^{\circ}$ C.

3. duration limits of development phases:

a from sporulation to germination : 2 hours $\ldots \ldots \ldots \ldots$ to 5 days

b from germination to entry (infection) $\ldots \ldots \ldots \ldots \ldots, 2$ to 9 days

c from entry to translucent spot $\ldots \ldots \ldots \ldots \ldots \ldots \ldots, 3$ to 10 days

$\mathrm{d}$ from stage 1 to sporulation $\ldots \ldots \ldots \ldots \ldots \ldots \ldots, 6$ to 9 days

one generation $\ldots \ldots \ldots \ldots \ldots \ldots \ldots \ldots \ldots \ldots \ldots \ldots \ldots, 11$ to 28 days 


\section{BLISTER BLIGHT INCIDENCE IN THE FIELD}

\section{The development phases}

In unshaded plantings the influence of light and humidity is fairly uniform. Since this influence implies a.o. a frequent prevalence of germicidal and retarding factors as to Exobasidium vexans, germination is more or less restricted to certain germination days, whilst the development phase $(a+b)$ most often covers a period of 4 , sometimes 5 days, as is borne out by observations. For secondary attacks arising under less favourable conditions it may be as long as 9 days. Under shade entry may be achieved in 2 days.

During the above period $(a+b)$ the fungus is susceptible to external influences (weather conditions or chemical control measures).

Period c (from entry to translucent spot) is of decisive importance for the purpose of creating forecasting systems, since the "first visible outbreak", to be determined with the unaided eye, is a distinct moment. If it is known how many days have elapsed since infection it is possible to ascertain the moment before which fungicides should have been applied to prevent the attack.

In unshaded plantations period $\mathrm{c}$ will, under conditions conducive to attacks, usually last 3 days in the case of the first visible outbreak. Blister blight incidence will increase from the 4 th to the 7 th day because more blisters reach the translucent spot stage after 4 to 7 days.

Chemical disease control should therefore have taken place at least 4 days before the first visible signs of an epidemic. Consequently warnings should be issued before the 4th day preceding an outbreak. Where long intervals between applications (6 to 7 days' rounds) are usual, warnings have to be given 10 or more days before the outbreak becomes visible.

For the short round application (3 days or less), which the author recommends, warnings given 8 or 7 days before the outbreak are ideal; those issued 6 to 5 days before the outbreak fairly good; those issued 4 days before very risky, and all later warnings are undoubtedly too late.

\section{Field observations}

Field observations for the purpose of designing a blister blight forecast system included observations regarding the identification of germination days. For this purpose object slides with spores can be placed into the plantation in the evening. The next day the microscope will reveal whether or not germination took place in the early morning hours.

Under heavy shade most days are germination days; in plantations with few or no shade trees germination days are in the minority.

Blister blight epidemics under shade will give rise to repeated severe secondary attacks in which blister incidence is much higher than in the primary epidemic. In this case one speaks of a "build-up"-period. If in unshaded plots a primary attack has been successfully suppressed either by climatic conditions or by chemical treatment, a secondary attack will not occur unless weather conditions would justify the expectation of a primary one at that moment.

The first limitation of the infection danger is the occurrence of fixed germination days, a second limitation being the fact that not all germinations lead 
to infections. There are, again, infection days and non-infection days. Under shade there are more infection days than in shadeless plantations.

Observations for the purpose of recognizing infection days can be made with marked leaves artificially covered with spores.

The days of outbreak were determined by counting blisters in the translucent spot stage in a sample of 30 arbitrarily chosen plucking shoots (pekoe +2 ). The number of blisters in such a sample received the name of blister number (for the stages 1 and 2); this is the unit in which the incidence degree was expressed by the author. In his thesis (33) he showed that this criterion is superior to blister numbers in stages 1 to 7 and to numbers or weights of blistered leaves, criteria adopted by other research workers.

\section{Influence of weather factors}

As a low r.h. and direct sunlight have a marked effect on Exobasidium vexans, it is desirable to establish the relation of weather factors to periods of enhanced blister blight incidence, epidemics.

\section{a. Relative air humidity}

The r.h. has a direct bearing on the incidence of infections and epidemics. Although there is an undeniable relation between the macroclimatic r.h. of the atmosphere and the microclimatic r.h. in an air layer of, say, $1 \mathrm{~mm}$ thick around a tea leaf, they need not be the same.

Spores drifting in the air above a planting are subject to the influence of the macroclimatic r.h. Spores lying on a leaf are liable to the influence of the microclimatic r.h.

aa Macroclimatic r.h.

The atmospheric humidity measured $2 \mathrm{~m}$ above the soil is indirectly related to solar radiation because it is dependent on radiation emanating from the surface of the earth heated by sun rays. Because of air movements, of which f.i. a dry wind is an example, the r.h. need not be closely related to the radiation on the spot.

Though the microclimatic r.h. may influence blister blight spores, which are also exposed to solar radiation, the ultra-violet rays are apparently of more importance.

\section{ab Microclimatic r.h.}

It is in the thin air layer upon and under a leaf blade that germination and subsequent infection will take place. High or low microclimatic r.h. will favour or impede germination and penetration; it is of the utmost importance to encourage the occurrence of factors conducive to a decrease of the microclimatic r.h.. Sunshine is most significant in this respect. Solar radiation heats the leaf blades. Part of it is absorbed, another part reflected. Evaporation in the air layer upon the leaf surface takes place as long as liquid water is present. After that, a saturation deficit may occur. In this way the microclimatic r.h. may become lower than the sumultaneous macroclimatic r.h. in the observation cabin.

For killing spores by desiccation a r.h. of 50 per cent or less is required during several consecutive hours, so that in the usually prevailing circum- 
stances the desiccating effect of low r.h. will not cause spores to die. These circumstances imply that every night a r.h. of 100 per cent, involving dew formation, will prevail during a period of 12 or more hours, so that a resumption of water ingestion will be possible. This means that partly desiccated spores can recover and regain their germination capacity.

A relatively low r.h. during daytime may sometimes entrain spore mortality, in general its importance lies in the fact that it checks germination. Whether or not spore germination will take place during subsequent night hours is consequently a matter of spore viability.

\section{b. Direct sunlight}

There is a close relation between direct sunlight (or its absence) and the occurrence of blister blight epidemics.

Macroclimatically spores in the atmosphere are subject to solar radiation in two ways, indirectly by r.h. decrease, and directly by its fungicidal influence.

(a) The intensity of direct sunlight depends on the elevation of the point of observation above sea level; at higher altitudes the atmospheric absorption of sun rays is lower. On an estate situated at $6.000 \mathrm{ft}$. elevation LAOH and Homburg (15) noted that complete blisters were killed after 1 or 2 sunny days.

The intensity of u.v. sunlight in relation with the elevation of the observation spot was studied by $\operatorname{Vrry}(31)$, who furnished the following relative u.v. values :

Table 5 .

\begin{tabular}{ll|l|l}
\hline & & \multicolumn{2}{|c}{ Sun's altitude } \\
& & $45^{\circ}$ & $65^{\circ}$ \\
\hline Djakarta $\ldots \ldots \ldots \ldots$ & 20.4 & 38.9 \\
Tjibodas $(1.400 \mathrm{~m})$ & $\cdots$ & 26.3 & 46.8 \\
Pangrango $(3.000 \mathrm{~m})$ & $\cdots$ & 37.2 & 60.3 \\
\hline
\end{tabular}

As the highest tea plantations are situated at $2.000 \mathrm{~m}$ the significance of these radiation intensities should not be overestimated. But meanwhile the temperature in low country tea estates is considerably higher than at greater elevations, so that in the low country the saturation deficit tends to be greater; this implies that, when only the desiccating effect of sunlight is considered, the altitude above sea level is decisive. When radiation is to be given attention to, the considerations have to apply to sunlight at a fixed elevation and are not applicable to estates situated at other altitudes.

(b) The duration of the daily direct sunshine can easily be assessed by any clerk if use is made of the common old-fashioned Jordan sunshine autographs. If sunshine data are used to replace r.h. data no sensitive or expensive hygrometers are required. This led Homburg (10) and VAN DER KNAAP (13) to design new forecasting systems on the basis of hours of sunshine. The earlier (r.h.-)system of Homburg (9) was abandoned.

The author's opinion is that sunshine, because of its effect, irrespective of the fact that it decreases the r.h., is more important than the latter and that 
it is the primary fungicidal factor, the r.h. being second. This does not imply that the relation between insolation and r.h., which HoMBurg (10) and VAN DER KNAAP (13) wished to make use of, is unimportant.

(c) The importance of morningsun has always been stressed by both planters and scientists. It was generally believed that afternoon sunshine is of minor importance. The idea of sunshine discrimination was agreed to by Homburg $(9,10)$ and Van Der KnaAp $(13)$ but contested by HuYsmans (11) and DE WEILE (33). HombURG was struck by the r.h. increase during the afternoon hours, even when there was considerable afternoon sunshine, and concluded that the effect of afternoon sun is much inferior to that of morning sun and can almost be ignored.

This must be a meteorological misunderstanding. The effect of terrestrial radiation is often so much higher in the afternoon as to outbalance solar radiation, but this is not necessarily attributable to a decrease of the latter.

Whereas morning sunshine will lower the macroclimatic r.h., afternoon sunshine may keep it low during a longer period than would have been the case without it and may prevent early dew formation. In most tea regions the average number of sunshine hours after the (completely arbitrary) local time of 12 o'clock is much smaller than before noon. By Homburg (9) this fact was not paid any attention to. Besides neither the direct light effects, - independent from the r.h. or the time of the day -, found by the author, nor his statistical field data support the idea of sunshine discrimination.

Direct insolation in the morning easily causes the r.h. to decrease to $\leqslant 83$ per cent, at which level spore formation stops (Huysmans, 11). Direct sunshine also halts or retards germination processes and kills spores and their still more vulnerable germ tubes.

And as a low r.h. does not kill spores unless it is as low as 50 per cent, or less, the author assumed that insolation provides the best basis for a forecasting system. This assumption has been confirmed by statistical material.

\section{c. Diffuse daylight}

As discussed earlier diffuse light is a regulating factor, which at low intensities favours the rapid development of Exobasidium vexans in the preinfection stages, while exposure to higher intensities tends to cause these periods of the fungus' life cycle to take more time. At different wave lengths, the energy level at which inversion of this effect occurs, is also different (De WeILLE, 33, 34, 35). Light quantities still promoting germination if $\lambda$ $\geqslant 525 \mathrm{~m} \mu$, can inhibit it if $\lambda<525 \mathrm{~m} \mu$. This is in accordance with results obtained with monochromatic u.v. light of various wave lengths to which other fungi were exposed by LuYet (19) and Oster (20). Pomper and ATwood (21) even found stimulation of the growth of various yeasts and Mucors to be brought about by very low doses of u.v. light, whereas retarding and destructive effects depend on $\lambda$ and the doses of radiant energy.

The longer the duration of the vulnerable stage of the fungus, i.e. the time during which it is outside the tissues of the tea leaf, the greater the chance that fungicidal factors will kill it, so that the significance of bright diffuse light is by no means inconsiderable. As subdued diffuse light favours the 
development of the fungus, it becomes still clearer that any form of shade or shadow (by remaining shade trees after thinning) in a tea plantation should be reduced as much as possible in order to give maximum access to light.

There still remains shade in the bushes. Leaves under shade are illuminated by light scattered by air molecules.

According to Rayleigh's law, scattering by air molecules is inversely proportionate to $\lambda^{4}$, so that the dispersion of u.v. radiation exceeds that of the blue rays $(\lambda=0.4 \mu)$, which are dispersed to a larger degree than red rays $(\lambda=0.7 \mu)$. The ratio $\frac{\text { diffuse radiation }}{\text { total sunlight }}$ is greater for u.v. rays than for violet and greater for violet then for red, so that diffuse light contains proportionally more u.v. rays than direct sunlight. In consequence, if all has been done to remove all shade in the plantations, the amount of u.v. light that still reaches tea leaves in ("internal") shade, is not inconsiderable.

\section{d. Rainfall}

Rainfall during night hours and rainfall intensity are merely of technical importance through the washing-off effect on fungicidal deposits. These is a weak relation of rainfall duration during daytime and sunshine duration. Any direct relation to blister blight epidemics could not be found.

\section{e. Mist}

Mist is one of the factors determining sunshine duration. It also covers the leaves with a thin layer of water, which favours germination.

\section{f. Cloudiness}

Cloudiness is important because it prevents sunshine and, in consequence thereof, determines sunshine duration.

\section{g. Wind}

Wind bears no relation to sunshine duration and is the factor still insufficiently studied.

As a movement of dry or moist air masses the wind is a matter that takes us back to the factor r.h..

Concerning the Siantar tea area some remarks about one often powerful type of wind, the "bohorok", cannot be omitted. This North Sumatra bohorok is comparable to the föhn, the sirocco and the chinook, being rapidly descending air, heated up by a certain degree of compression and arriving at the foothills as a warm dry wind, which causes a sharp rise in temperature and a distinct decrease of r.h.. This effect is already distinctly marked at an elevation of $3.000 \mathrm{ft}$.. At "Bah Butong" and "Sidamanik" it has been known to decrease the r.h. to 40 per cent; then it is extremely fungicidal. Sunshine and bohorok do not always coincide; the paradoxical combination of an overcast sky and a r.h. lowered by wind is well-known in the tea growing centre Pematang Siantar where cloudy bohorok days occur.

Fungicidal wind effect is dependent on wind velocity too. Reports from Java mention practically no blister incidence on certain steep, rather heavily shaded slopes, exposed to frequent or persistent strong winds (not dry as the 
bohorok), whereas on off-wind slopes of a similar character blister blight inflicted serious damage.

A logical explanation for the fungicidal effect may be found in the desiccation a strong wind causes.

The fungicidal effect of strong wind may, at least partly, explain why blister blight attacks that have been forecast, sometimes do not develop or prove to be less severe than expected. In the usual forecasting systems the wind is not taken into account. To do so is technically rather difficult.

\section{h. Thermals}

Though they bear no relation to blister blight incidence thermals are very important in the field of its control. Vaporization and temperature-increase in the morning cause a rising air current. Its strength may place a limit on the dusting period. In W. Java tea estates dusting has to be performed before 8.30 a.m.. Later on the dust cloud is lifted up so high that it is dispersed over a vast area or borne several hundreds of metres away from the plantation to be dusted. At "Rantjasuni" tea estate dusting was performed from 5.15 or 5.30 to 7 or 7.30 a.m.. Later dusting was obviously useless. When necessary, dusting was resumed from 4 to 6 p.m.. It is self-evident that, for practical reasons, thermals have to be duly taken into account.

\section{i. Temperature}

Apart from terrain conditions the elevation of an estate or a plantation is to a high degree decisive for its liability to blister blight (VAN EMDEN and Reitsma, 3).

Closely related to the elevation is the general temperature, about which VAN DER KNAAP (13) states: "the lower the temperature, the slower the germination". There is a certain optimum since the same worker found temperatures of $35^{\circ} \mathrm{C}$ and higher to be lethal to blister blight spores.

The low up-country temperature, particularly on sloping plantations such as the Patuha tea estates, where huge air masses ascend the slopes, entails considerable condensation as the air masses are more or less saturated with water vapour originating from vaporization in the lowlands. So the factor elevation contains more than just temperature differences.

\section{f. Elevation}

As compared with low country estates situation at a relatively high elevation implies :

1 lower temperature;

2 higher r.h.;

3 more interruptions of direct sunshine; the duration of cloudy or rainy spells caused by condensation of ascending air masses is reflected in sunshine recorder slips;

4 somewhat higher insolation intensity, especially in regard to u.v. radiation (Vru, 31).

The interruptions of direct sunshine counteract the fungicidal properties of the latter, so that, in spite of the somewhat higher u.v. intensity, a high elevation is in favour of the blister blight fungus. This consideration provides an explanation for the fact that the blister blight susceptibility of "Bah Birung 
Ulu" estate $(2.100 \mathrm{ft})$ is less than that of nearby "Sidamanik" and „Bah Butong" $(2.700 \mathrm{ft})$. This fairly slight difference in elevation does not show in the number of sunshine hours nor in the r.h. and scarcely in the temperature. The number of interruptions during sun hours, greater at higher altitude, must have been decisive in this case.

The blister blight susceptibility of "Balimbingan" estate (from $900 \mathrm{ft}$ onward) is less than that of "Kasinder" $(1.500 \mathrm{ft})$, which is distinctly less liable to the disease than "Bah Birung Ulu". All of these estates are in the Siantar area.

With insolation for a basis, the susceptibility of a plantation depends on its elevation and, - a secondary factor -, its site, the situation of a planting with respect to its environment. In Java the sloping Patuha estates are more liable to the disease than the Pengalengan plateau estates situated at comparable elevations.

While criteria for the purpose of warnings will only hold good for a fixed elevation level, site and wind may be used as local correctives.

\section{THE FORECASTING OF BLISTER BLIGHT ATTACKS}

Once the best possible microclimate for natural blister blight control has been obtained by the application of indirect methods (cultivation measures), this will suffice so long as climatic conditions remain unfavourable for the fungus; as soon as weather conditions favour the latter, direct control by spraying, mist blowing or dusting becomes necessary.

If exact criteria can be found in order to determine when the moment for using fungicides has arrived and, conversely, at what point chemical treatment may be stopped, the treatment can be interrupted without the risk of missing an attack. On the other hand it should not happen that chemical treatment is wasted.

With a view to economizing on fungicides and labour and at the same time to safeguarding tea estates against unexpected blister blight outbreaks with their inherent crop losses, several alarm systems have been devised on the basis of 5 day averages of r.h. (Huysmans, 11; Homburg, 9), 5 day averages of morning sunshine duration (Homburg, 10) or sunshine score numbers (VAN DER KNAAP, 13). The latter author's strange score list shows a strong discrimination between a.m. and p.m. sunshine in favour of morning sunshine. Both Homburg (10) and VAN DER KNAAP (13) used sunshine hours as a substitute for r.h..

In an earlier and more extensive publication (33) the author described and criticized the abovementioned systems, which take no account of the direct fungicidal and regulating effects of insolation. In order to replace the system of Huysmans-Wijbrans (ameliorated Huysmans-system) he introduced, - in 1957 -, his new s.v.r. system, based on revalued total daily sunshine durations.

\section{The s.v.r. system of chemical control}

The author's method of chemical blister blight control is based on 1) short treatment rounds, a principle extensively dealt with in an other publication (33) and 2) warnings according to an alarm system based on total daily sunshine, indicated by the name s.v.r. (sun valuation rate) system. 


\section{Short rounds}

Contrary to the current advice that dusts require shorter application rounds (f.i. 5 days) than sprays (7-10 days) (LAMB, 14; Loos, 17), in the author's opinion fungicidal treatment rounds of 3 days are advisable, whether spraying or dusting is applied.

In the first place, pekoe's are entirely unfolded after 4 days, while all second leaves will have doubled their surface during that time, so that a substantial part of the young foliage will not be protected by the fungicidal layer.

Secondly, account has to be taken of the period during which an ungerminated spore or a newly formed germ-tube may be damaged by fungicidal preparations and of the sticking capacity of the fungicide.

As stated, the matter is discussed in detail elsewhere (33). The conclusion was that 3 days' rounds are ideal; 4 or even 5 days' rounds are still possible, but longer rounds are not advisable. Experiments with rounds of different durations substantiated this conclusion.

Three days' rounds the author considers to be short; treatment rounds of 6 or more days he calls long (33). In the "s.v.r." warning system the application of 3 days' rounds is assumed.

\section{The prelude to an epidemic}

Certain periods, deficient in sunshine, may bring on a blister blight attack. Such a period is followed by a spell of 4 to 5 days during which climatic conditions, often unfavourable to blister blight, cannot counteract the effect of the preceding period. This period of 4 to 5 days is the incubation time of the attack (therefore not the incubation time of a particular infection by a particular spore).

After this incubation period an increase of blisters in the first translucent spot stage will appear.

Knowledge of the blister-inducing (sunshine-deficient) period helped evolve the s.v.r. system.

1 The effect of the sunshine on a certain day is not proportional to the duration of sunshine on that day. Days poor in sunshine should be given less weight. Accordingly revaluation has to be applied, resulting in a closer correlation between (revalued) sunshine hours and blister blight attacks. It could be shown that the best method is the following one :

a sunshine durations of less than 1 hour are considered to be 0 ;

b all longer (daily) durations are diminished by 1 .

2 The order in which fungicidal and fungus-promoting days occur within one week previous to the incubation days is of the utmost importance. Later days in the period can entirely or partly nullify the influence of earlier days.

Statistical trials were performed with the data regarding blister numbers at "Bah Butong" tea estate in the period from the 1st May, 1953, until the end of that year. As a result of these systematic trials co-ordination appeared to occur in accordance with the following.

Conclusive for the degree of blister incidence are in particular 3 critical 
days within the course of one week in which these three days turn the balance. The "build-up" of an attack is the result of (successively):

a 3 days with an average sunshine deficiency, to be awarded the weight co-efficient 1;

b 3 days, following the former three and having a greater effect, which must be awarded a weight co-efficient 2 ;

c 1 day, sometimes to be considered as the first incubation day, which, if extreme, may still check the expected development (weight co-efficient 1);

d 4 or more post-infection days, preceding the first increase of blisters in the initial stage of development; these (incubation) days can no longer affect the development of an attack.

\section{Calculation of sun valuation rates}

Be the sunshine durations $d$ of the various days $a_{1}, a_{2}, a_{3}, b_{1}, b_{2}, b_{3}$ and $c$; when the revalued sunshine hours $d^{\prime}$ are indicated as $a^{\prime}{ }_{1}, a^{\prime}{ }_{2}, a^{\prime}{ }_{3}, b^{\prime}{ }_{1}, b^{\prime}{ }_{2}$, $\mathrm{b}^{\prime}{ }_{3}$ and $\mathrm{c}^{\prime}$, the sun valuation rate of date $c$, - a new concept proceeding from the application of the results stated in $2-$, would be $\Sigma_{\mathrm{w}}\left(\mathrm{d}^{\prime}\right)=$ $a^{\prime}{ }_{1}+a^{\prime}{ }_{2}+a^{\prime}{ }_{3}+2 b^{\prime}{ }_{1}+2 b^{\prime}{ }_{2}+2 b^{\prime}{ }_{3}+c^{\prime}$, a weighted sum of revalued sunshine durations.

(The smallest time unit used is $1 / 4 \mathrm{hr}$ ).

Revaluation according to 1 ( $\mathrm{d}<1 \longrightarrow \mathrm{d}^{\prime}=0$

$\mathrm{d}>1 \rightarrow \mathrm{d}^{\prime}=\mathrm{d}-1$ ) can be simplified by increasing $\Sigma_{\mathrm{w}}\left(\mathrm{d}^{\prime}\right)$ by 10 with the only consequence that danger limits indicated by s.v.r.'s are also increased by 10 .

Revaluation then becomes $\mathrm{d} \leq 1 \rightarrow \mathrm{d}^{\prime}=1$

$\mathrm{d}>1 \rightarrow \mathrm{d}^{\prime}=\mathrm{d}$. Or in words : durations shorter than 1 hour become 1 ; longer durations remain unchanged.

From these partly revalued data the s.v.r. is calculated according to the formula

$$
\text { s.v.r. }=a^{\prime}{ }_{1}+a^{\prime}{ }_{2}+a^{\prime}{ }_{3}+2 b^{\prime}{ }_{1}+2 b^{\prime}{ }_{2}+2 b^{\prime}{ }_{3}+c^{\prime} .
$$

Supposing that at " $\mathrm{X}$ " estate the following numbers of sunshine hours have been registered on successive days :

$31 / 4,6,7,4,2,1 / 2,0,5,0,2,9,6,5,8$ (hrs), the revalued sun rates will successively be

$31 / 4,6,7,4,2,1,1,5,1,2,9,6,5,8$.

From the 7 th day onward the sun valuation rates are

$$
\begin{array}{rlrl}
31 / 4+6+7+8+4+2+1 & & 311 / 4 \\
6+7+4+4+2+2+5 & & 30 \\
7+4+2+2+2+10+1 & =28 \\
4+2+1+2+10+2+2 & =23 \\
2+1+1+10+2+4+9 & =29 \\
1+1+5+2+4+18+6 & =37 \\
1+5+1+4+18+12+5 & =46 \\
5+1+2+18+12+10+8 & =56
\end{array}
$$




\section{Application}

The sun valuation rate proved to be the determining unit for blister blight occurrence. Danger limits derived from them indicate when chemical control must be started (or resumed) and when it may be stopped after completing the round in progress.

For East Coast estates or plantations between 2600 and $3100 \mathrm{ft}$ above sea level ("Bah Butong", "Sidamanik") the danger limit is 40. For "Bah Birung Ulu" at $2100 \mathrm{ft}$ it is $32 \frac{1}{2}$. Such limits can be assessed locally, so that the system is adapted to local conditions just by altering the danger limits indicated by the s.v.r.'s.

As to "Bah Butong" estate it appeared that as soon as the s.v.r. becomes less than 40 , which can be determined on the respective day at 6 p.m., control must immediately be started the next morning and in a short round.

\section{Implications are :}

1 the estate should have enough power dusters or other engine driven units to allow application rounds of 3 working days. Short rounds are essential for any good blister blight control;

2 it should have so many knapsack sprayers that susceptible plots (nurseries, moist and shady allotments, newly pruned plantings) and plantings beyond the reach of larger equipment can be treated too in short rounds if required;

3 a network of paths especially laid out for small tractors on behalf of disease control is supposed to be present (DE WetLle, 36);

4 it seems advisable that on each estate one person should be in charge of the daily assessment of the s.v.r. and responsible for arranging blister blight control for the following day, if indicated by the sun valuation rate;

5 the s.v.r. system necessitates having a gang of labourers who are always prepared for two kinds of work, e.g. pruning and, when the need arises, spraying.

On an estate where the s.v.r. danger limit is not yet known, this will have to be calculated by the employee concerned. This can be done by counting Ist and 2nd stage blisters on 30 shoots ( 2 leaves and a bud) arbitrarily chosen from the daily harvest. By regularly keeping a blister number/s.v.r. diagram a tentative danger limit can be determined after a 3 months' period of changing weather. Later definite limits can be fixed.

Comparative tests of warning systems

In order to support the argumentation with practical evidence long-term tests were worked out in which the system's efficacy was compared with that of "competing" systems.

There was statistical material concerning "Bah Butong" tea estate covering the period from 1st January, 1952 to and incl. 31st October, 1956 and a similar amount of statistical data concerning "Bah Birung Ulu" estate. In 1957 the data concerning "Bah Butong" were published in the appendix to the author's thesis (33).

The period of almost 5 years stated above contained 48 blister blight epiphytotics of differring severity. 
Table 6.

\begin{tabular}{|c|c|c|c|c|c|c|}
\hline $\begin{array}{l}\text { Systems } \\
\text { (with literature nrs) }\end{array}$ & $\begin{array}{l}\text { Denoted } \\
\text { by }\end{array}$ & $\begin{array}{l}\text { Criteria for } \\
\text { drawal of }\end{array}$ & $\begin{array}{l}\text { warning }(+) \text { or } w \\
\text { of the warning }(-)\end{array}$ & & & \\
\hline s.v.r.-system (33) & svr & s.v.r. $\lesseqgtr$ local dange & $\begin{aligned} & \text { limit }(=40) \\
&, \quad(=40)\end{aligned}$ & $:$ & + & 一 \\
\hline Huysmans (11) ...... & $\mathrm{Hs}$ & (5-day averages of $x$ & $\begin{array}{l}\text { r.h.) } \\
6 \text { days } \geqq 83(\%) \\
3 \text { days }<83\end{array}$ & $:$ & + & - \\
\hline Huysmans-WijBrans & $\mathrm{Hs}-\mathrm{W}$ & & $\begin{array}{l}6 \text { days } \geqq 80 \\
3 \text { days }<80\end{array}$ & $:$ & + & 一 \\
\hline Hombung I (9) & No I & & $\begin{array}{l}3 \text { days } \geqq 80 \\
5 \text { days }<80 \\
\end{array}$ & $:$ & + & - \\
\hline Homburg II (10) $\ldots$. & No II & (5-day averages of & $\begin{array}{l}\text { a.m. sunshine) } \\
3 \text { days }>3(\text { hrs }) \\
5 \text { days } \geq 3\end{array}$ & $:$ & + & - \\
\hline Adapted Homburg II .. & ad. Ho II & & $\begin{array}{l}3 \text { days } \ 21 / 4 \\
5 \text { days } \geqq 21 / 4\end{array}$ & $\begin{array}{l}: \\
:\end{array}$ & + & - \\
\hline VAN DER KNaAP (13) & $\mathrm{vdK}$ & $\begin{array}{l}\text { (sunshine scores) } \\
10 \text { days, of which } \\
\text { subsequent days : }\end{array}$ & $\begin{array}{l}5 \text { days } \geq 6 \\
5 \text { days } \geq 5 \\
5 \text { days } \geq 6\end{array}$ & $\begin{array}{l}: \\
:\end{array}$ & $\begin{array}{l}+ \\
+\end{array}$ & — \\
\hline Adapted vaN DER KNAAP & ad. vdK & $\begin{array}{l}10 \text { days, of which } \\
\text { subsequent days : } \\
, "\end{array}$ & $\begin{array}{l}5 \text { days } \geqq 7 \\
5 \text { days } \geqq 6 \\
5 \text { days } \geqq 7\end{array}$ & $\begin{array}{l}: \\
:\end{array}$ & $\begin{array}{l}+ \\
+\end{array}$ & - \\
\hline
\end{tabular}

In order to give Java systems an equal chance in the tests, they were studied in two forms, i.e. in the original form in which they were applied by their designer, and in an adapted form, modified (following their originator's directives) to conform to climatological conditions on Sumatra's East Coast.

In the following pages only the "Bah Butong" test will be discussed.

\section{The systems compared}

The original and, as far as "Bah Butong" is concerned, the modified systems implied in the tests, were the ones summed up in table 6 .

No modifications have been made in regard to the number of days during which a weather factor has to exceed the assumed critical level for issuing or withdrawing warnings. This would interfere with the character of the systems themselves. The adaptations relate only to the danger limit expressed by the adapted criterion.

An adapted system Homburg I would be equal to the original Ho I, so that no separate column has to be reserved for it.

\section{Registration of attacks}

Periods of increased blister blight incidence, - epidemics, epiphytotics or attacks -, may be of varying duration. On the one hand there are "periods" of 1 day; on the other hand attacks may last 2 months.

In the case of one-day attacks the statistical value of single observations is so disputable that it seems justified to take special precautions. The occurrence of prolonged periods of more or less serious blister incidence warrants 
the assumption that differentiation between independent attacks and "build-up" phenomena would be in order.

For the purpose of listing the attacks the following rules were adopted:

1 A blister blight attack is a period during which blister blight incidence, expressed in blister numbers recorded in stages 1 and 2, amounts to 35 or more. (If recorded in stages $1-7$, they have to amount to 50 or more).

2 In order to be registered as an attack the blister number in single day attacks has to exceed 40 (stages $1-2$; or 60 in st. 1-7).

3 Interruptions of 1 or 2 days with blister numbers below the critical level will not be taken into account. The occurrence of 3 or more non-critical days within a period of increased blister incidence will warrant registration as a separate attack of the period following this break.

4 Blister numbers collected in shaded plots (Jan.-Apr., 1954) will not be taken into account.

5 Blister numbers recorded in stages 1-2 are considered more representative than those recorded in stages 1-7 (DE WeILLE, 33).

6 Epidemics are discriminated after their severity according to table 7 .

Table 7.

\begin{tabular}{|c|c|c|c|c|}
\hline \multicolumn{4}{|c|}{ Duration of the attack } & \multirow{4}{*}{ Classification } \\
\hline$\geqq 2$ days & 1 day & $\geqq 2$ days & 1 day & \\
\hline \multicolumn{4}{|c|}{ Blister numbers } & \\
\hline \multicolumn{2}{|c|}{ stages $1-2$} & \multicolumn{2}{|c|}{ stages $1-7$} & \\
\hline $\begin{array}{r}35 \\
\vdots \\
\vdots 0 \\
70 \\
\geqq 100\end{array}$ & $\begin{array}{l}>40 \\
>55 \\
>75 \\
>105\end{array}$ & $\begin{array}{rr}\gtreqless & 50 \\
\gtreqless & 80 \\
\gtreqless & 115 \\
\geqq & 160\end{array}$ & $\begin{array}{l}>60 \\
>90 \\
>125 \\
>170\end{array}$ & $\begin{array}{l}\text { minor attack } \\
\text { considerable incidence } \\
\text { serious incidence } \\
\text { heavy attack }\end{array}$ \\
\hline
\end{tabular}

Each attack was studied within a frame of 15 days. The days before the visible onset of an epidemic were denoted by $-10,-9, \ldots \ldots,-1$, the day of the outbreak by 0 and the days following the outbreak by $+1,+2,+3$ and +4. The attacks were summarized (DE WeLLe, 33; appendix, pp. 59-64).

In order to be able to compare the various alarm systems, the author classified the warnings given under any of them by grouping them around one principal class (case 2). The cases distinguished are stated in table 8 .

With the help of the classification in table 8 it has been possible to determine how many early, timely or late warnings would have been issued under each system, had it been applied at "Bah Butong" during the period covered by the author's study. In case $2 \mathrm{a}$ ) account is taken of the spray retention.

\section{The results}

If we neglect 2 attacks under shade, 46 attacks had to be warned against. Table 9 gives a survey of the comparative results.

During the longer (1st) period of 31\% years, containing not less than 31 blister blight attacks, the results were in favour of the s.v.r. system. During the 2nd period, when, unfortunately enough, the statistically less ideal blister numbers in the stages 1-7 had to be made use of, the system missed 3 attacks. Two of them were of minor importance and one was a long term attack (from 


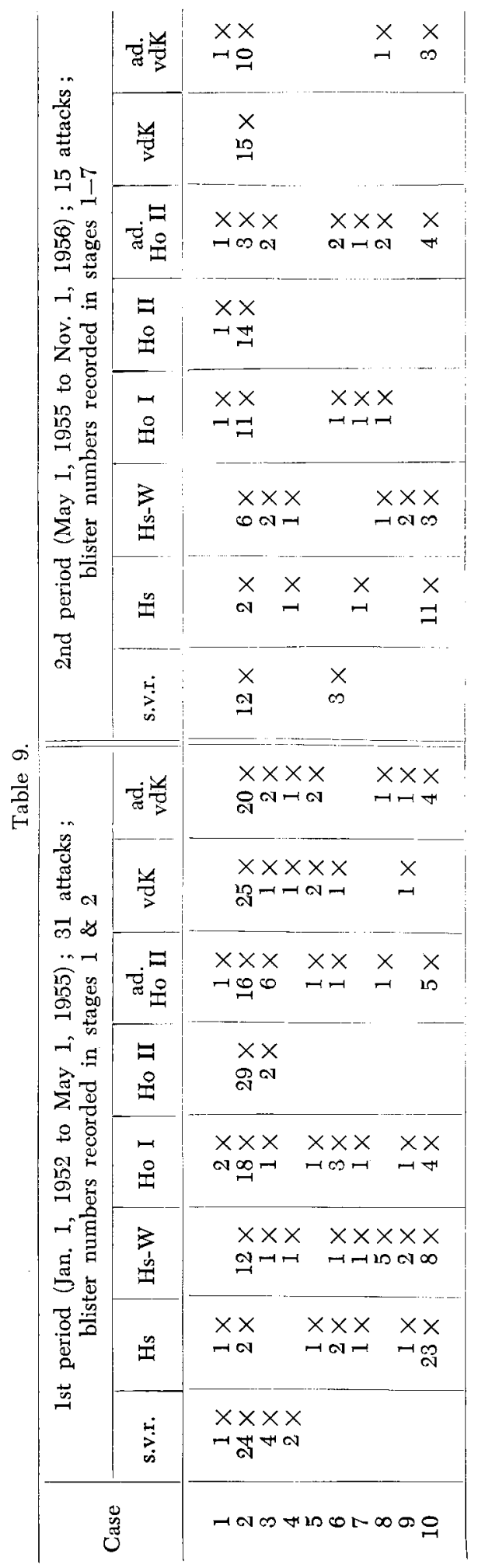


Table 8.

\begin{tabular}{|c|c|c|}
\hline Case & Description & Valuation \\
\hline 1 & $\begin{array}{l}\text { A warning is issued or still in force } 10 \text { and/or } 9 \\
\text { days before an attack's (visible) outbreak (day }-10 \\
\text { and/or -9), but withdrawn the next day; }\end{array}$ & $\begin{array}{l}\text { somewhat early if short } \\
\text { ( } 3 \text { days' treatment rounds } \\
\text { are applied ; adequate } \\
\text { ones when applying long } \\
\text { (6-7 days') rounds }\end{array}$ \\
\hline 2 & $\begin{array}{l}\text { a) in case } 1 \text {, but at day }-4 \text { or earlier a new } \\
\text { warning is given; } \\
\text { b) warning issued or in force } 8 \text { and/or } 7 \text { days be- } \\
\text { fore outbreak; } \\
\text { warning issued } 6 \text { or } 5 \text { days before outbreak; pre- } \\
\text { ceding days are - days; }\end{array}$ & correct \\
\hline 4 & $\begin{array}{l}\text { warning issued } 4 \text { days before outbreak; preceding } \\
\text { days -; }\end{array}$ & risky \\
\hline 5 & $\begin{array}{l}\text { warning issued } 4 \text { days before outbreak; preceding } \\
\text { days -; }\end{array}$ & late \\
\hline 6 & $\begin{array}{l}\text { warning issued } 2 \text { or } 1 \text { days before outbreak; pre- } \\
\text { ceding days -; }\end{array}$ & late \\
\hline 7 & first warning issued at day of outbreak; & late \\
\hline 8 & $" \quad " \quad, \quad 1$ or 2 days after outbreak ; & late \\
\hline 9 & $" \quad " \quad, \quad 3$ or 4 days after outbreak; & late \\
\hline 10 & no warning at all & - \\
\hline
\end{tabular}

24-9-56 to 31-10-56 and later) of which the initial phase was missed; during the various "build-up" periods the s.v.r. system required almost continuous treatment.

When cursorily studying table 9 we obtain the impression that s.v.r. is second to Ho II. This is due to the fact that by excessive warnings Ho II cannot miss an attack. Does the Homburg II-system, in case its number of + days ${ }^{1}$ ) is logically reduced to about the same number as in the s.v.r. system, still equal or surpass the latter? This question may also apply to the system of VAN DER KNAAP.

Table 10.

\begin{tabular}{|c|c|c|}
\hline & + & - \\
\hline $\begin{array}{l}\text { s.v.r. } \ldots \ldots \ldots \\
\text { Hs } \ldots \ldots \ldots \\
\text { Hs-W } \ldots \ldots \ldots \\
\text { Ho I } \ldots \ldots \ldots \\
\text { Ho II } \ldots \ldots \\
\text { ad. Ho II } \ldots \ldots \\
\text { vdK } \ldots \\
\text { ad. vdK } \ldots \ldots \\
\ldots\end{array}$ & $\begin{array}{r}832 \\
112 \\
578 \\
898 \\
1454 \\
841 \\
1219 \\
910\end{array}$ & $\begin{array}{r}934 \\
1654 \\
1188 \\
868 \\
312 \\
925 \\
547 \\
856\end{array}$ \\
\hline
\end{tabular}

1) Chemical treatment days. 
The numbers of + and - days during the test period according to the various systems are summarized in table 10, which confirms the author's opinion that, at least for North Sumatra, the s.v.r. system gives the best solution to the problem of forecasting blister blight.

A recent publication by Visser, Shanmuganathan and Mulder (30) shows that in Ceylon the possibilities of making use of sunshine records for the purpose of timing spraying rounds, advocated by the author $(34,35)$, are paid attention to. Visser et al. have performed trials in this field and found that a spray-timing system, based on sunshine data, shows considerable promise for application on a field scale.

Due to the "bohorok" (see page 199) some expected attacks did not develop. Bohorok days can reduce the quantity of infective material to such an extent that also the first attack expected after a bohorok period becomes of minor importance. During and after bohorok days a temporary correction of s.v.r.'s seems justified. Investigations of the wind factor may improve the system further and may lead to further economy in fungicides and labour.

Meanwhile on the basis of the knowledge now available no unexpected blister blight attacks need occur.

\section{REFERENCES}

1 EMdEN, J. H. van : Aantekeningen over enige ziekten en plagen van de thee. De Bergcultures, 20 (9) May 1, 1951; pp. 152-167.

2 - - and W. F. van HeLl : Blisterblight. De Bergcultures 20 (11), January 1, 1951 ; pp. 7-9.

3 - - and J. Rertsma : De bladpokkenziekte van de thee (2). De Bergcultures 18 (18), September 16, 1949 ; pp. 370-377.

4 -, , - : Verslag van een studiereis naar Ceylon en Zuid-India, teneinde de blisterblightziekte van de thee te bestuderen. Archief voor de Theecultuur, part 17 (I), April 1950 ; pp. 5-70.

5 GADD, C. H.: The collection of blistered leaves. Tea Quarterly, XIX (I), May 1947 ; pp. 17-20.

6 - - and C. A. Loos: The basidiospores of Exobasidium vexans. Transactions British Mycol. Society, XXXI (III/IV), 1948 ; pp. 229-233.

$7--,--:$ Further observations on the spore growth of Exobasidium vexans. Trans. Br. Myc. Soc. 33 (1/2), 1950 ; pp. 19-21.

8 Hell, W. F. vaN and H. VeEnstra: Voorlopige resultaten van een tweetal proeven ter bestrijding van de blisterblightziekte in gesnoeide theetuinen. Mededelingen van het Algemeen Proefstation der A.V.R.O.S. (A.P.A.), Alg. serie no. 61. Also in Arch. Theecult. 17 (2); December 1950; pp. 77-111.

9 Homburg, K. : Een beschouwing over het klimaat i.v.m. de bestrijding van Exobasidium vexans. De Bergcultures 22 (2), January 16, 1953; pp. 31-39.

10 - - : Enige resultaten van de blisterblightbestrijdingsproeven in het Patuha'se. De Bergcultures 24 (7), April 1, 1955 ; pp. 169-185.

11 Huxsmans, C. P.: Bestrijding van blisterblight (Exobasidium vexans) in thee op Sumatra. De Bergcultures 21 (21), November 1, 1952 ; pp. 419-464.

12 Jong, P. DE: Recent development in the control of blister blight of tea in South India. Plant protection overseas review 4 (2), 1954.

13 KNAAP, W. P. vaN DER: Notes on disease incidence of Exobasidium vexans Massee on tea. Arch. Theecult. 19 (2), October 1955 ; pp. 99-113.

14 LAMB, J. : Crop protection by wet spraying compared with crop protection by dusting in 1951. Tea Quart., XXIII (I), March 1952; pp. 12-14.

15 LAOH, J. Ph. and K. Homburg : Blisterblightwaarnemingen en bestrijdingsproeven in het Patuha'se. De Bergcultures 22 (16).

16 Loos, C. A. : The causative fungus. Tea Quart. XXII (II), June 1951 ; pp. 63-72. 
17 - - : Studies in blister blight control XI : Dusting against blister blight on Alupoll group, Ratnapura. Tea Quart. XIII (III), September 1952; pp. 76-80.

18 - - : Rep. Pathological Div. 1953. Tea Inst. Ceylon; Bull. no. 35.

19 LuYET, B. J.: The effects of ultra-violet, X- and cath. rays on the spores of Mucoraceae. Radiology, XVIII (5), May 1932 ; pp. 1019-1022.

20 Oster, R. H.: Results of irradiating Saccharomyces with monochromatic ultra-violet light. III : The absorption of ultra-violet energy by yeast. Jour. Gen. Physiol. 18, 1934 ; pp. 251-254.

21 Pomper, S, and K. C. Atwood: Radiation studies on fungi. Rad. Biology II, Chapter 11, pp. 431-453. Ed. by A. Hollaender. McGraw Hill Book Comp. Inc., NewYork, 1955 .

22 Rainfall Records 1956. Communications Gen. Expt. St. of the A.V.R.O.S.; Gen. Series no. $66,1958$.

23 Reitsma, J. and J. H. van EMden: De bladpokkenziekte van de thee. De Bergcultures 18 (12), June 16, 1949 ; pp. 218-231.

$24-\ldots,-$ : $^{-}$De bladgallenziekte van de thee in Indonesië. Arch. Theecult. 17 (1), April 1950 ; pp. 71-76.

25 Schwerzer, J.: De situatie inzake de blisterblightziekte van de thee op Sumatra's Oostkust. De Bergcultures 19 (10), May 16, 1950; pp. 207-211.

$26--$ and J. Rertsma : Blisterblightsituatie in de bevolkingstuinen in het Sukabumische. De Bergcultures 20 (13), July 1, 1951 ; pp. 231-235.

27 Sntjoers, J. H. : Bodembescherming en blisterblight. De Bergcultures 21 (7), April 1, 1952 ; pp. $139-145$.

28 Statistieknummer. De Bergcultures 25 (3), February 1, 1956 ; pp. 101-107.

29 Tunbs, F. R. : Blister blight. Tea Quart. XIX (I), May 1947; pp. 9-13. And Discussion, pp. 13-19.

30 Visser, T., N. Shannuganathan and P. Mulder: The possibility of timing blister blight spraying according to sunshine records. Tea Quart. XXX (I), March 1957; pp. 39-43.

31 VRIJ, M. P.: Vergelijkende metingen van ultraviolette zonnestraling in de tropen en in Europa. Thesis, Amsterdam, $1932 ; 65$ p.

32 WeILLE, G. A. DE: De fungicide werking van licht van verschillende golflengten ten aanzien van blister blight. Berichten Alg. Proefst. A.V.R.O.S, no. 1, December 6, 1956. Also in De Bergcultures 26 (7), 1957 ; pp. 149-157.

33 - - : Blister blight control in its connection with climatic and weather conditions. Thesis Bogor; March 1957; 172 pp. Also in Archives of tea cultivation 20, 1960 ; in the press.

34 - - : Mogelijkheden voor het voorspellen van epidemiën van door schimmels veroorzaakte plantenziekten, geboden door het gebruik van zonneschijngegevens. Ber. A.P.A. no. 8, November $1957 ; 6$ p.

$35--$ : Possibilities offered by the use of sunshine data for the purpose of forecasting epidemics of fungous plant diseases. Ber. A.P.A. no. 9, November 1957; 6 p.

36 - - : A treatise on chemical control of blister blight. Ber. A.P.A. no. 14, June 1958; 41 p. Also in Arch. Tea Cult. 20, 1960; in the press.

37 - - : The adaption of tea cultivation to the presence of blister blight. Arch. Tea Cult. 20, 1960; in the press. 